\title{
Delayed Sowing Dates Affected Alfalfa Overwintering Survival Rates by Reducing Soil Temperature Stress
}

\author{
Ai-Min Zhu ${ }^{1,2}$, Qing-Xin Zhang ${ }^{1}$, Xiao-Yan Du ${ }^{1}$, Xian-Guo Wang ${ }^{3}$, Yu-Xia Zhang ${ }^{1,}$, \\ Guo-Dong Han', Bai-Ming Cong ${ }^{4}$, Yong-Lei Tian ${ }^{5}$ \\ ${ }^{1}$ Agricultural College, Inner Mongolia University for Nationalities, Tongliao, China \\ ${ }^{2}$ College of Grassland, Resources and Environment, Inner Mongolia Agricultural University, Hohhot, China \\ ${ }^{3}$ College of Grassland Science and Technology, China Agricultural University, Beijing, China \\ ${ }^{4}$ Laboratory of Animal Nutrition and Feed, Tongliao Institute of Agriculture and Animal Husbandry, Tongliao, China \\ ${ }^{5}$ Grassland Research Institute, Academy of Agriculture and Animal Husbandry Sciences, Hohhot, China
}

\section{Email address:}

yuxiazhang685@163.com (Yu-Xia Zhang)

${ }^{*}$ Corresponding author

\section{To cite this article:}

Ai-Min Zhu, Qing-Xin Zhang, Xiao-Yan Du, Xian-Guo Wang, Yu-Xia Zhang, Guo-Dong Han, Bai-Ming Cong, Yong-Lei Tian. Delayed Sowing Dates Affected Alfalfa Overwintering Survival Rates by Reducing Soil Temperature Stress. Journal of Plant Sciences.

Vol. 9, No. 4, 2021, pp. 214-223. doi: 10.11648/j.jps.20210904.22

Received: July 27, 2021; Accepted: August 26, 2021; Published: August 31, 2021

\begin{abstract}
This study explored the effect of sowing time on alfalfa overwintering and its mechanisms. Gongnong No. 1 alfalfa was sown on July 1, July 16, August 1 and August 15, 2017, and was not cut at the end of autumn. The soil temperature changes in the 10 and $20 \mathrm{~cm}$ soil layers were monitored during the overwintering period, and bare land was monitored as a control. The growth characteristics of alfalfa were observed at the end of autumn, and the overwintering survival rate was measured at the end of April 2018. Research shows that as the sowing delay increased, the alfalfa hay yield, plant height, root collar diameter and overwintering survival rate decreased gradually. The minimum temperature of the 10 and $20 \mathrm{~cm}$ soil layers decreased as the sowing delay increased, and the diurnal temperature difference increased. Compared with that of alfalfa sown on August 15, the aboveground biomass of alfalfa sown on July 1 increased the average minimum temperature difference in the 10 and $20 \mathrm{~cm}$ soil layers by $3.12^{\circ} \mathrm{C}$ and $2.99^{\circ} \mathrm{C}$, respectively, and reduce the average diurnal temperature difference by $3.33^{\circ} \mathrm{C}$ and $2.15^{\circ} \mathrm{C}$. These results indicated that delaying alfalfa sowing reduces the cover on the field, which results in substantial differences in the minimum temperature and the diurnal temperature difference between the 10 and $20 \mathrm{~cm}$ soil layers. Our research has suggested that the minimum temperatures of the 10 and $20 \mathrm{~cm}$ soil layers and the increase in the diurnal temperature difference are important reasons for low overwintering survival rates in alfalfa. Therefore, sowing should occur in early July, and mowing should not be performed at the end of autumn in northern China.
\end{abstract}

Keywords: Alfalfa, Overwintering Rate, Soil Temperature, Sowing Time

\section{Introduction}

Alfalfa (Medicago sativa L.) is a high-quality perennial leguminous forage that has strong stress resistance and a long cultivation history [1-2]. As the forage with the largest cultivated area and the highest economic value in the world, alfalfa plays an important role in the development of animal husbandry worldwide. Overwintering in alfalfa is a complex process [3]; in many cases, plant damage is caused by a combination of multiple stresses, and many complex factors determine the survival of alfalfa plants. Previous studies have shown that whether alfalfa plants can safely survive the winter depends on the cold resistance of their roots. With the decreases in temperature and sunshine hours in autumn, most alfalfa varieties will transport nutrients from their aboveground parts to their roots for storage [4]. In addition, research has shown that the larger the diameter of the alfalfa root collar is, the stronger the cold tolerance of the plant is [5].

However, the selection of the sowing time is a key factor 
in alfalfa cultivation techniques. A suitable sowing time allows the alfalfa plants to make full use of light, water, fertilizer, heat and other resources so that they can grow healthily and cope with adverse environments. In modern agricultural science, suitable sowing dates for various crops have been obtained through rigorously designed staged sowing experiments and long-term meteorological data analysis [6]. However, there are still many problems in alfalfa production in the Horqin area, Inner Mongolia, which is known as "China's Grass Capital". Among them, unstable winter survival rates and frequent freezing damage have become some of the major problems that seriously restrict the large-scale production of alfalfa in this area [7-8]. The frequent occurrence of alfalfa freezing damage in the Horqin sandy land has caused great losses and has seriously restricted sustainable alfalfa production in the Horqin sandy land. The manifestations of climate change are difficult to predict; as early as 2002, Belanger pointed out that a reduction in snowfall and an increase in freezing rain are potential factors that could increase the occurrence of plant freezing damage in the future [9].

Cold resistance in alfalfa depends not only on its genetic characteristics but also on environmental factors [10-11]. The term "cover" refers to a variety of substances that are used to protect and improve the surface conditions of soil. Film mulching is one of the most widely used techniques in agricultural production. Previous studies on potatoes [12], tomatoes [13] and other crops [14] have shown that film mulching can increase crop yields by increasing the soil temperature. Li et al [15] studied the effect of film mulching on grape overwintering and showed that film mulching could increase the overwintering survival rate of grapes by increasing the soil temperature. However, the use of mulch in large-scale alfalfa production to resist cold damage and improve yields would be very expensive. Therefore, the focus of this study is to determine whether, if the alfalfa crop is not mowed at the end of autumn, the biomass of the remaining crop stubble could be used as a suitable cover to help alfalfa roots safely survive the winter. This information would be of use to herders and enterprises planting alfalfa in northern China.

With this goal, the research team for this study cooperated with a company that plants alfalfa in the Horqin area. The growth characteristics of Gongnong No. 1 alfalfa varieties in different sowing dates at the end of autumn were observed, and the temperature changes in the $10 \mathrm{~cm}$ and $20 \mathrm{~cm}$ soil layers at different sowing levels were detected. In addition to the overwintering survival rate of alfalfa, the relationships between the sowing period and the overwintering soil temperature, growth characteristics and overwintering survival rate of alfalfa were analyzed. The aim of this study was to determine an appropriate sowing time that would allow alfalfa to survive winter safely in the Horqin sandy land, reveal the mechanisms of soil temperature change under alfalfa sown on different sowing dates, and provide a theoretical basis for efficient alfalfa cultivation in this area.

\section{Method}

\subsection{Experimental Conditions}

The experimental site was located at the forage production base of Huinong Grassland Co., Ltd. in Arukeerqin Banner, Chifeng city, Inner Mongolia Autonomous Region, China. Its geographical location is $42^{\circ} 30^{\prime} 50.4^{\prime \prime}$ north latitude, $115^{\circ} 27^{\prime} 34.2^{\prime \prime}$ east longitude, at $322 \mathrm{~m}$ above sea level. The area has a temperate semiarid continental climate with an average annual temperature of $5.5^{\circ} \mathrm{C}$, an accumulated $>10^{\circ} \mathrm{C}$ temperature of $3000-3200^{\circ} \mathrm{C}$, a frost-free period of $140-$ 150 days, an average annual precipitation of approximately $375 \mathrm{~mm}$, and an average annual wind speed of $3.0-4.4 \mathrm{~m} \mathrm{~s}^{-1}$. The soil in the area is a sandy loam soil.

\subsection{Soil Conditions}

The soil in the experimental plot contained $38.8 \mathrm{mg} \mathrm{kg}^{-1}$ alkali-hydrolyzed nitrogen, $2.1 \mathrm{mg} \mathrm{kg}^{-1}$ available phosphorus, $103 \mathrm{mg} \mathrm{kg}^{-1}$ available potassium, and $7.28 \mathrm{mg} \mathrm{kg}^{-1}$ organic matter and had a $\mathrm{pH}$ value of 7.26.

\subsection{Experimental Design}

The experiment was conducted from July 2017 to April 2018. Sowing was performed on July 1, July 15, August 1 and August 15, 2017. The sowing rate was $22.5 \mathrm{~kg} \cdot \mathrm{hm}^{-2}$, and sowing was performed by mechanical drilling. The plots were arranged at random. Each plot was $3 * 4=12 \mathrm{~m}^{2}$, and each sowing date plot had 4 replicates, for a total of 16 plots. There were $0.5 \mathrm{~m}$ corridors between each of the plots. At the end of autumn, the alfalfa plants were not mowed, and the aboveground alfalfa plants in each plot were retained as mulch. There were four levels of mulch, corresponding to the four sowing dates. Temperature detectors were installed in one of the plots for each sowing date to monitor the soil temperature at $10 \mathrm{~cm}$ and $20 \mathrm{~cm}$ soil depth in real time. The soil temperature at $10 \mathrm{~cm}$ and $20 \mathrm{~cm}$ soil depth was also measured in a plot that was not sown with alfalfa, as a control.

\subsection{Materials}

The experimental variety was Gongnong No. 1 alfalfa (Medicago sativa L.) provided by the Grassland Institute of the Jilin Academy of Agricultural Sciences, China.

\subsection{Sampling Times and Methods}

On October 15, 2017, the aboveground biomass, plant height and stem diameter of alfalfa sown on the different sowing dates were measured, and the overwintering survival rate of alfalfa was determined in late April 2018.

Hay yield

In each plot, $1 \mathrm{~m}^{2}$ of alfalfa was mowed, and $5 \mathrm{~cm}$ of stubble was left on the field. The alfalfa was weighed immediately after mowing, and the fresh weight was recorded. Then, $200 \mathrm{~g}$ fresh samples were put into nylon mesh bags and brought back to the laboratory for drying. The 
fresh samples were first heated at $105^{\circ} \mathrm{C}$ for 15 minutes to stop biological activity and then dried to a constant weight at $65^{\circ} \mathrm{C}$. The dry-fresh ratio, equivalent to the hay yield per hectare, was then calculated.

\section{Root collar diameter}

The diameter of the alfalfa root collar (where tillering occurs) was measured by a Vernier caliper. Ten plants were randomly measured in each plot, and the average value of the measurements was used as the root collar diameter for the data analysis.

\section{Plant height}

The natural growth height from the top to the root of the alfalfa plant was measured. Thirty plants were randomly measured in each plot, and the average height value was used as the average plant height in the data analysis.

Branch number per plant

The number of branches from the root crown of each alfalfa plant was determined for 30 plants from each plot.

Overwintering survival rate

Surviving and dead alfalfa plants were counted at fixed sites. Overwintering survival rate $(\%)=$ the number of surviving plants/the total number of alfalfa plants investigated $* 100$.

\subsection{Data Processing and Analysis}

The test data were recorded, plotted and calculated with Microsoft Excel 2010 software. SPSS software was used to analyze the differences in plant height, overwintering survival rate, root crown diameter, hay yield and branch number per plant for the alfalfa sown on different sowing dates (one-way ANOVA) and to determine the correlation between the overwintering survival rate and the plant height, root crown diameter, hay yield, branch number per plant and temperature of the different soil layers (Pearson correlation analysis).

\section{Results and Analysis}

\subsection{Analysis of the Correlation Between Overwintering Survival Rate and Hay Yield, Stem Diameter and Temperature in Different Soil Layers}

As shown in Table 1, the correlation analysis showed that the overwintering survival rate of alfalfa was positively correlated with the aboveground hay yield and the root collar diameter before overwintering but that these correlations were not significant. There was a significant positive correlation between the overwintering survival rate of alfalfa and the plant height and the number of branches per plant. In addition, there was a significant positive correlation between the overwintering survival rate and the minimum temperature in the $10 \mathrm{~cm}$ and $20 \mathrm{~cm}$ soil layers in November, December, January, and February and the maximum temperature in the $20 \mathrm{~cm}$ soil layer in November. There was a significant positive correlation between the overwintering survival rate and the maximum temperature and diurnal temperature difference in the $10 \mathrm{~cm}$ soil layer in March and April and the diurnal temperature difference in the $10 \mathrm{~cm}$ soil layer in November, December, January, and February.

Table 1. Analysis of the correlation between the overwintering survival rate and the hay yield, root collar diameter, plant height, number of branches per plant, and temperature in different soil layers.

\begin{tabular}{|c|c|c|c|c|c|c|c|c|c|c|}
\hline Index & Hay yield & $\begin{array}{l}\text { Root collar } \\
\text { diameter }\end{array}$ & Height & $\begin{array}{l}\text { Branches } \\
\text { per plant }\end{array}$ & $\begin{array}{l}\text { Nov-10 cm- } \\
\text { Min. T }\end{array}$ & $\begin{array}{l}\text { Dec-10 cm- } \\
\text { Min. T }\end{array}$ & $\begin{array}{l}\text { Jan-10 cm- } \\
\text { Min. T }\end{array}$ & $\begin{array}{l}\text { Feb-10 cm- } \\
\text { Min. T }\end{array}$ & $\begin{array}{l}\text { Mar-10 cm- } \\
\text { Min. T }\end{array}$ & $\begin{array}{l}\text { Apr-10 cm- } \\
\text { Min. T }\end{array}$ \\
\hline $\begin{array}{l}\text { Correlation } \\
\text { coefficient }\end{array}$ & 0.948 & 0.888 & $0.968^{*}$ & $0.972 *$ & $-0.991 * *$ & $-0.967 *$ & $-0.977 *$ & $-0.989^{*}$ & -0.795 & -0.893 \\
\hline Index & $\begin{array}{l}\text { Nov-10 cm- } \\
\text { Max. T }\end{array}$ & $\begin{array}{l}\text { Dec-10 cm- } \\
\text { Max. T }\end{array}$ & $\begin{array}{l}\text { Jan-10 cm- } \\
\text { Max. T }\end{array}$ & $\begin{array}{l}\text { Feb-10 cm- } \\
\text { Max. T }\end{array}$ & $\begin{array}{l}\text { Mar-10 cm- } \\
\text { Max. T }\end{array}$ & $\begin{array}{l}\text { Apr-10 cm- } \\
\text { Max. T }\end{array}$ & $\begin{array}{l}\text { Nov-10 cm- } \\
\text { Diu. T }\end{array}$ & $\begin{array}{l}\text { Dec-10 cm- } \\
\text { Diu. T }\end{array}$ & $\begin{array}{l}\text { Jan-10 cm- } \\
\text { Diu. T }\end{array}$ & $\begin{array}{l}\text { Feb-10 cm- } \\
\text { Diu. T }\end{array}$ \\
\hline $\begin{array}{l}\text { Correlation } \\
\text { coefficient }\end{array}$ & -0.680 & 0.146 & 0.449 & 0.935 & $0.990 * *$ & $0.960 *$ & $0.997 * *$ & $0.981 *$ & $0.986^{*}$ & $0.992 * *$ \\
\hline Index & $\begin{array}{l}\text { Mar-10 cm- } \\
\text { Diu. T }\end{array}$ & $\begin{array}{l}\text { Apr-10 cm- } \\
\text { Diu. T }\end{array}$ & $\begin{array}{l}\text { Nov- } 20 \mathrm{~cm}- \\
\text { Min. T }\end{array}$ & $\begin{array}{l}\text { Dec- } 20 \mathrm{~cm}- \\
\text { Min. T }\end{array}$ & $\begin{array}{l}\text { Jan- } 20 \mathrm{~cm}- \\
\text { Min. T }\end{array}$ & $\begin{array}{l}\text { Feb- } 20 \mathrm{~cm}- \\
\text { Min. T }\end{array}$ & $\begin{array}{l}\text { Mar- } 20 \mathrm{~cm}- \\
\text { Min. T }\end{array}$ & $\begin{array}{l}\text { Apr-20 cm- } \\
\text { Min. T }\end{array}$ & $\begin{array}{l}\text { Nov- } 20 \mathrm{~cm}- \\
\text { Max. T }\end{array}$ & $\begin{array}{l}\text { Dec- } 20 \mathrm{~cm}- \\
\text { Max. T }\end{array}$ \\
\hline $\begin{array}{l}\text { Correlation } \\
\text { coefficient }\end{array}$ & $0.996 * *$ & $0.961 *$ & $-0.999 * *$ & $-0.964 *$ & $-0.976^{*}$ & $-0.985 *$ & -0.641 & -0.804 & $-0.993 * *$ & -0.906 \\
\hline Index & $\begin{array}{l}\text { Jan-20 cm- } \\
\text { Max. T }\end{array}$ & $\begin{array}{l}\text { Feb- } 20 \mathrm{~cm}- \\
\text { Max. T }\end{array}$ & $\begin{array}{l}\text { Mar-20 cm- } \\
\text { Max. T }\end{array}$ & $\begin{array}{l}\text { Apr-20 cm- } \\
\text { Max. T }\end{array}$ & $\begin{array}{l}\text { Nov-20 cm- } \\
\text { Diu. T }\end{array}$ & $\begin{array}{l}\text { Dec- } 20 \mathrm{~cm}- \\
\text { Diu. T }\end{array}$ & $\begin{array}{l}\text { Jan-20 cm- } \\
\text { Diu. T }\end{array}$ & $\begin{array}{l}\text { Feb-20 cm- } \\
\text { Diu. T }\end{array}$ & $\begin{array}{l}\text { Mar-20 cm- } \\
\text { Diu. T }\end{array}$ & $\begin{array}{l}\text { Apr-20 cm- } \\
\text { Diu. T }\end{array}$ \\
\hline $\begin{array}{l}\text { Correlation } \\
\text { coefficient }\end{array}$ & -0.922 & -0.575 & 0.703 & 0.396 & $1.000 * *$ & $0.982 *$ & $0.985^{*}$ & $0.973 *$ & 0.910 & 0.704 \\
\hline
\end{tabular}

Note: **: Represents a significant correlation at the 0.01 level $(P<0.01)$, *: Represents a significant correlation at the 0.05 level $(P<0.05)$. Nov-10 cm-Min. T, Dec-10 cm-Min. T, Jan-10 cm-Min. T, Feb-10 cm-Min. T, Mar-10 cm-Min. T and Apr-10 cm-Min. T refer to the average minimum temperature of the 10 $\mathrm{cm}$ soil layer in the corresponding month. Nov-10 cm-Max. T, Dec-10 cm-Max. T, Jan-10 cm-Max. T, Feb-10 cm-Max. T, Mar-10 cm-Max. T and Apr-10 cmMax. T refer to the average maximum temperature of the $10 \mathrm{~cm}$ soil layer in the corresponding month. Nov-10 cm-Diu. T, Dec-10 cm-Diu. T, Jan-10 cm-Diu. T, Feb-10 cm-Diu. T, Mar-10 cm-Diu. T and Apr-10 cm-Diu. T refer to the average diurnal temperature difference in the $10 \mathrm{~cm}$ soil layer in the corresponding month. Nov-20 cm-Min. T, Dec-20 cm-Min. T, Jan-20 cm-Min. T, Feb-20 cm-Min. T, Mar-20 cm-Min. T and Apr-20 cm-Min. T refer to the average minimum temperature of the $20 \mathrm{~cm}$ soil layer in the corresponding month. Nov-20 cm-Max. T, Dec-20 cm-Max. T, Jan-20 cm-Max. T, Feb-20 cm-Max. T, Mar-20 cmMax. T and Apr-20 cm-Max. T refer to the average maximum temperature of the $20 \mathrm{~cm}$ soil layer in the corresponding month. Nov- $20 \mathrm{~cm}-\mathrm{Diu}$. T, Dec- $20 \mathrm{~cm}-$ Diu. T, Jan-20 cm-Diu. T, Feb-20 cm-Diu. T, Mar-20 cm-Diu. T and Apr-20 cm-Diu. T refers to the average diurnal temperature difference in the $20 \mathrm{~cm}$ soil layer in the corresponding month. 


\subsection{Effects of Different Sowing Dates on the Growth Characteristics and Overwintering Survival Rate of Alfalfa}

As shown in Table 2, the plant height of alfalfa decreased as the sowing date became later. The plant height varied significantly among the different sowing dates. The plant height of the alfalfa sown on July 1 was significantly higher than that of the alfalfa sown on August 15. The yield of alfalfa hay decreased significantly as the sowing time delay increased. The highest hay yield was obtained from the alfalfa sown on July 1, which was significantly higher than the yields of alfalfa sown on other sowing dates. The hay yield from alfalfa sown on July 1 was significantly higher than that from alfalfa sown on August 15. There was no significant difference in root crown diameter between the alfalfa sown on July 1 and the alfalfa sown on July 15 and August 1 . The average root crown diameter of alfalfa sown on August 15 was $3.0 \mathrm{~mm}$, which was significantly smaller than those of the alfalfa plants sown on July 1, July 15 and August 1 .

The overwintering survival rate of alfalfa sown on July 1 was significantly higher than that of alfalfa sown on other sowing dates $(P<0.05)$. The overwintering survival rate of alfalfa sown on 15 July was significantly higher than that of alfalfa sown on 1 August and 15 August $(P<0.05)$. Early sowing in the Horqin Sandy Land is clearly beneficial to the survival of overwintering alfalfa. However, due to the low temperatures during the winter of 2017 - 2018, even the overwintering survival rate of alfalfa sown on July 1 was only $57.5 \%$. The number of branches per plant sown on July 1 was significantly higher than those of plants sown on other sowing dates $(P<0.05)$, but there were no significant differences in branch number among plants sown on other sowing dates.

Table 2. Effects of different sowing dates on the overwintering survival rate, hay yield, plant height and root crown diameter of alfalfa.

\begin{tabular}{llllll}
\hline Sowing date & Overwintering survival rate (\%) & Hay yield $\left.\mathbf{~ k g ~ h ~}^{-2}\right)$ & Height (m) & Root crown diameter (mm) & Branches per plant (number) \\
\hline July 1st & $57.5 \pm 11.0 \mathrm{a}$ & $4823.4 \pm 678.7 \mathrm{a}$ & $58.0 \pm 7.1 \mathrm{a}$ & $3.9 \pm 0.4 \mathrm{a}$ & $4.8 \pm 0.6 \mathrm{a}$ \\
July 15th & $32.4 \pm 19.0 \mathrm{~b}$ & $3467.7 \pm 436.3 \mathrm{~b}$ & $42.1 \pm 1.7 \mathrm{~b}$ & $3.5 \pm 0.3 \mathrm{ab}$ & $3.6 \pm 0.5 \mathrm{~b}$ \\
August 1st & $9.3 \pm 1.6 \mathrm{c}$ & $2581.2 \pm 413.4 \mathrm{c}$ & $27.4 \pm 1.8 \mathrm{c}$ & $3.1 \pm 0.3 \mathrm{~b}$ & $3.0 \pm 0.5 \mathrm{~b}$ \\
August 15th & $4.5 \pm 3.4 \mathrm{c}$ & $1071.6 \pm 254.4 \mathrm{~d}$ & $12.3 \pm 1.7 \mathrm{~d}$ & $2.2 \pm 0.1 \mathrm{c}$ & $3.1 \pm 0.5 \mathrm{~b}$ \\
\hline
\end{tabular}

Note: Different lowercase letters indicate significant differences within the same column $(P<0.05)$.

\subsection{Effect of the Sowing Date on Soil Temperature}

\subsubsection{Effect of the Sowing Date on the Minimum Soil Temperature}

As shown in Figures 1 and 2, the minimum soil temperature in the $10 \mathrm{~cm}$ soil layer began to fall below zero on November 13, and the differences in temperature among the plots with different sowing dates were obvious. The soil temperature under the alfalfa sown on July 1 dropped the least, followed by those under alfalfa sown on July 15 and bare land; the soil temperature under the alfalfa sown on August 15 dropped sharply. The minimum temperature in the $20 \mathrm{~cm}$ soil layer was slightly higher than that in the $10 \mathrm{~cm}$ soil layer, but difference was not significant.

The minimum soil temperatures in the $10 \mathrm{~cm}$ soil layer in December decreased by sowing date in the order July $1>$ July $15>$ August $1>$ bare land $>$ August 15, and the minimum soil temperature in the $20 \mathrm{~cm}$ soil layer decreased in the order July $1>$ July $15>$ August $15>$ bare land. The minimum soil temperature under the alfalfa sown in the different sowing dates was lower than $-5^{\circ} \mathrm{C}$ in December. There were two low-temperature periods during the study period that resulted in low temperatures below $-15^{\circ} \mathrm{C}$ in the $10 \mathrm{~cm}$ soil layer under the bare land and in the $20 \mathrm{~cm}$ soil layer under the alfalfa sown on August 15; however, the minimum soil temperature under the alfalfa sown on July 1 during these periods was approximately $-10^{\circ} \mathrm{C}$.

There were significant differences in the minimum soil temperatures in January among the treatments with different sowing dates; the temperatures by sowing date decreased in the order July $1>$ July $15>$ August $1>$ August 15 . In the 10 $\mathrm{cm}$ soil layer, the temperature under the alfalfa sown on August 15 was lower than that under bare land, while in the $20 \mathrm{~cm}$ soil layer, the temperature under the bare land was lower than that under the alfalfa sown on August 15. There were two low-temperature periods in January, and the lowesttemperature period occurred from January 21 to 29 . The minimum soil temperature in the $10 \mathrm{~cm}$ soil layer under the bare land and alfalfa planted on August 15 was lower than $20^{\circ} \mathrm{C}$, and the minimum soil temperature under the $20 \mathrm{~cm}$ soil layer in these plots was also close to $-20^{\circ} \mathrm{C}$. Temperature changes during this period are critical in determining whether alfalfa plants will freeze.

The soil temperatures began to rise gradually in February, but all of them remained below $-5^{\circ} \mathrm{C}$, and there were still significant differences among the treatments with different sowing dates. The soil temperatures by sowing date decreased in the order July $1>$ July $15>$ August $1>$ August 15 or bare land. From February 2 to February 7, the soil temperatures under the bare land and alfalfa sown on August 15 were lower than $-15^{\circ} \mathrm{C}$ in the $10 \mathrm{~cm}$ soil layer, while the minimum temperature under the alfalfa sown on July 1 was higher than that under bare land. The minimum temperature in the $20 \mathrm{~cm}$ soil layer under the bare land and the alfalfa sown on August 15 changed from February 3 to February 6 but remained lower than $-15^{\circ} \mathrm{C}$.

From March 13 to 23 , the minimum soil temperatures in the $10 \mathrm{~cm}$ and $20 \mathrm{~cm}$ soil layers were close to $0^{\circ} \mathrm{C}$. Starting on March 24, the minimum soil temperature rose above zero. 
The maximum soil temperature occurred on March 28, and the minimum soil temperature on that day was approximately $5^{\circ} \mathrm{C}$. The minimum soil temperatures under the plots with different sowing dates were significantly different during the first ten days of March but were not obviously different for the rest of March.

In April, the minimum soil temperatures in the $10 \mathrm{~cm}$ and $20 \mathrm{~cm}$ soil layers were above $0^{\circ} \mathrm{C}$. From April 3 to April 9, the soil temperatures were lower; that is, an obvious cold period occurred in late spring.

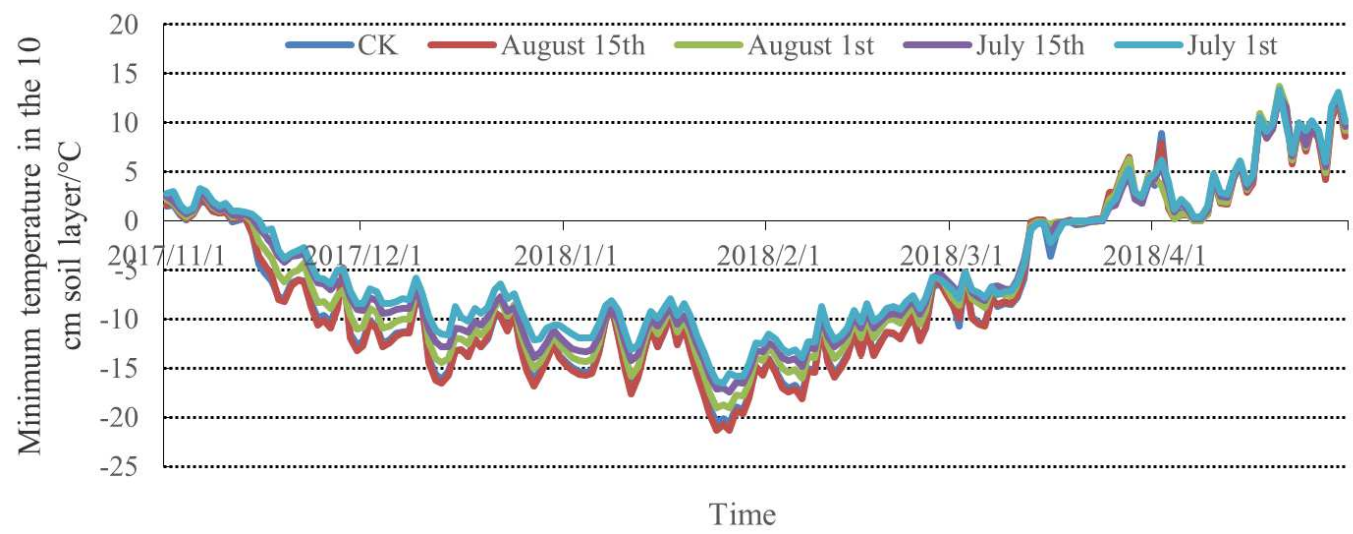

Figure 1. Change in the daily minimum temperature in the $10 \mathrm{~cm}$ soil layer from November 2017 to April 2018 under alfalfa sown on different sowing dates.

In the figure, CK refers to the minimum temperature in the $10 \mathrm{~cm}$ soil layer under bare land. July 1 , July 15 , August 1 and August 15 refer to the minimum temperature in the $10 \mathrm{~cm}$ soil layer under alfalfa sown on July 1, July 15, August 1 and August 15, respectively. The same as bellow.

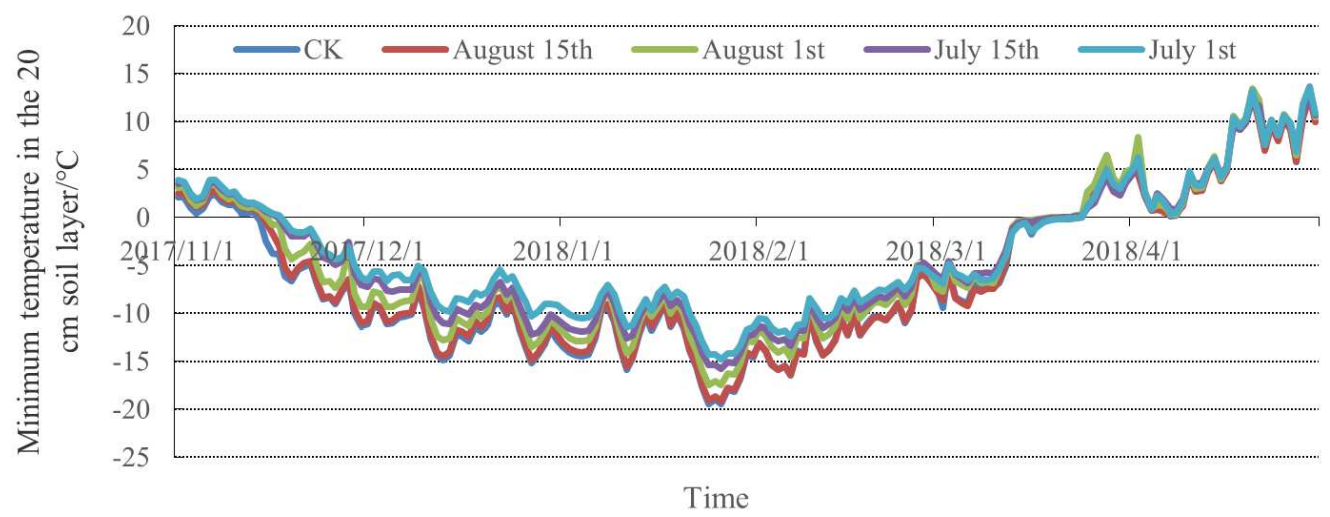

Figure 2. Change in the daily minimum temperature of the $20 \mathrm{~cm}$ soil layer from November 2017 to April 2018 under alfalfa sown on different sowing dates.

\subsubsection{Effect of the Sowing Period on the Maximum Soil Temperature}

As shown in Figures 3 and 4, the maximum temperature in November exhibited a short cooling period in early November and a slow cooling trend after November 7. The temperature in the $10 \mathrm{~cm}$ soil layer dropped to $0^{\circ} \mathrm{C}$ on November 15 and to below $-5^{\circ} \mathrm{C}$ at the end of November. There were no significant differences in the maximum temperature of the $10 \mathrm{~cm}$ soil layer among the treatments planted on the in different sowing dates. The maximum temperatures of the soil in the $20 \mathrm{~cm}$ soil layer were significantly different among the plots sown on different sowing dates, especially after November 10 . The maximum temperature in the plot seeded on July 1 was similar to that of the plot seeded on July 15, and temperatures fell to $0^{\circ} \mathrm{C}$ on November 19 and November 18, respectively. The maximum soil temperature under bare land was similar to that under the alfalfa sown on August 15, and the temperatures fell to $0^{\circ} \mathrm{C}$ on November 15 and November 16, respectively.

The maximum soil temperature in December was below $0^{\circ} \mathrm{C}$. In the $10 \mathrm{~cm}$ soil layer, the average maximum soil temperatures under bare land and under alfalfa sown on August 15 , August 1 , July 15 and July 1 were $-6.84^{\circ} \mathrm{C}$, $6.36^{\circ} \mathrm{C},-7.19^{\circ} \mathrm{C},-7.22^{\circ} \mathrm{C}$, and $-6.21^{\circ} \mathrm{C}$, respectively. The maximum soil temperature of the $20 \mathrm{~cm}$ soil layer was obviously different among treatments; the lowest values were observed in the plots sown on August 15, and the highest were observed in the plots sown on July 1 . The average maximum soil temperatures were $-7.31^{\circ} \mathrm{C},-7.44^{\circ} \mathrm{C},-6.96^{\circ} \mathrm{C},-6.74^{\circ} \mathrm{C}$, and $-6.02^{\circ} \mathrm{C}$ in the bare land and the plots with alfalfa sown on August 15, August 1, July 15 and July 1, respectively.

In January and February, there were no significant differences in soil temperature among the different sowing dates in the $10 \mathrm{~cm}$ or $20 \mathrm{~cm}$ soil layer. The maximum soil temperatures in the different soil layers in March varied significantly among treatments. The average maximum soil 
temperatures in the $10 \mathrm{~cm}$ soil layer under the bare land and the plots sown on 15 August, 1 August, 16 July and 1 July were $\quad 3.07^{\circ} \mathrm{C}, \quad 4.30^{\circ} \mathrm{C}, \quad 3.22^{\circ} \mathrm{C}, \quad 1.99^{\circ} \mathrm{Cand} \quad 1.38^{\circ} \mathrm{C}$, respectively, while those in the $20 \mathrm{~cm}$ soil layer were $1.92^{\circ} \mathrm{C}$, $1.21^{\circ} \mathrm{C}, 1.84^{\circ} \mathrm{C}, 0.52^{\circ} \mathrm{C}$, and $0.11^{\circ} \mathrm{C}$, respectively.

At the beginning of April, there was an obvious cooling period. The average maximum soil temperatures of the $10 \mathrm{~cm}$ soil layer under bare land and under alfalfa sown on 15
August, 1 August, 16 July and 1 July were $14.04^{\circ} \mathrm{C}, 14.73^{\circ} \mathrm{C}$, $14.36^{\circ} \mathrm{C}, 13.19^{\circ} \mathrm{C}$ and $12.81^{\circ} \mathrm{C}$, respectively, and those for the $20 \mathrm{~cm}$ soil layer were $17.99^{\circ} \mathrm{C}, 17.03^{\circ} \mathrm{C}, 17.77^{\circ} \mathrm{C}$, $14.96^{\circ} \mathrm{C}$ and $16.96^{\circ} \mathrm{C}$, respectively. The average daily maximum temperatures in the $10 \mathrm{~cm}$ and $20 \mathrm{~cm}$ soil layers under bare land and alfalfa sown on August 15 were higher than those in the other sowing treatments.

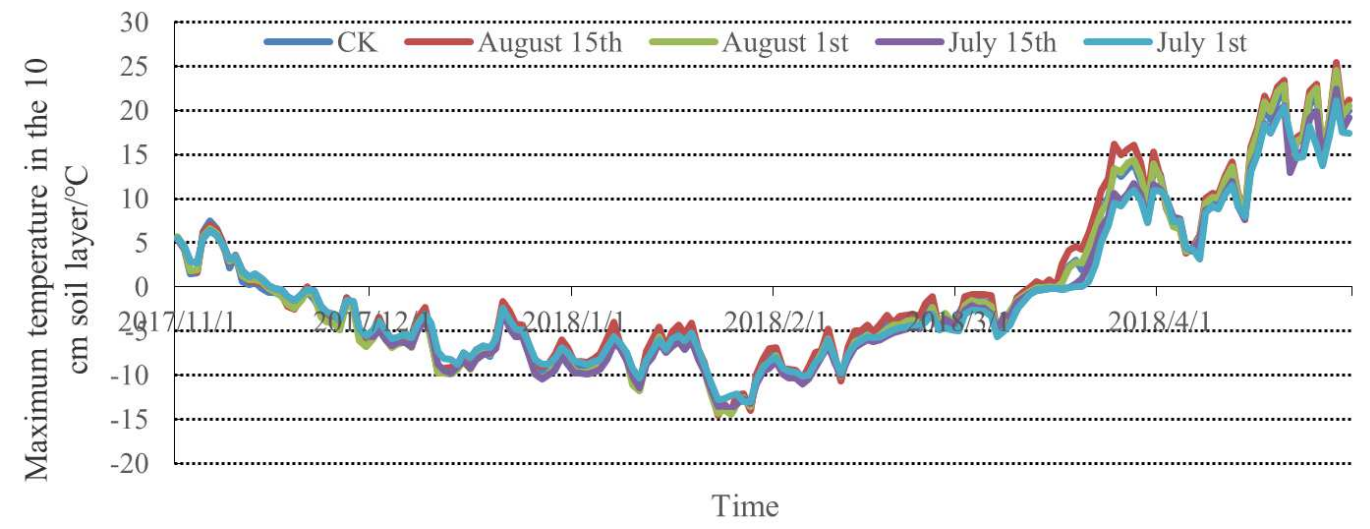

Figure 3. Change in the daily maximum temperature of the $10 \mathrm{~cm}$ soil layer from November 2017 to April 2018 under alfalfa sown on different sowing dates.

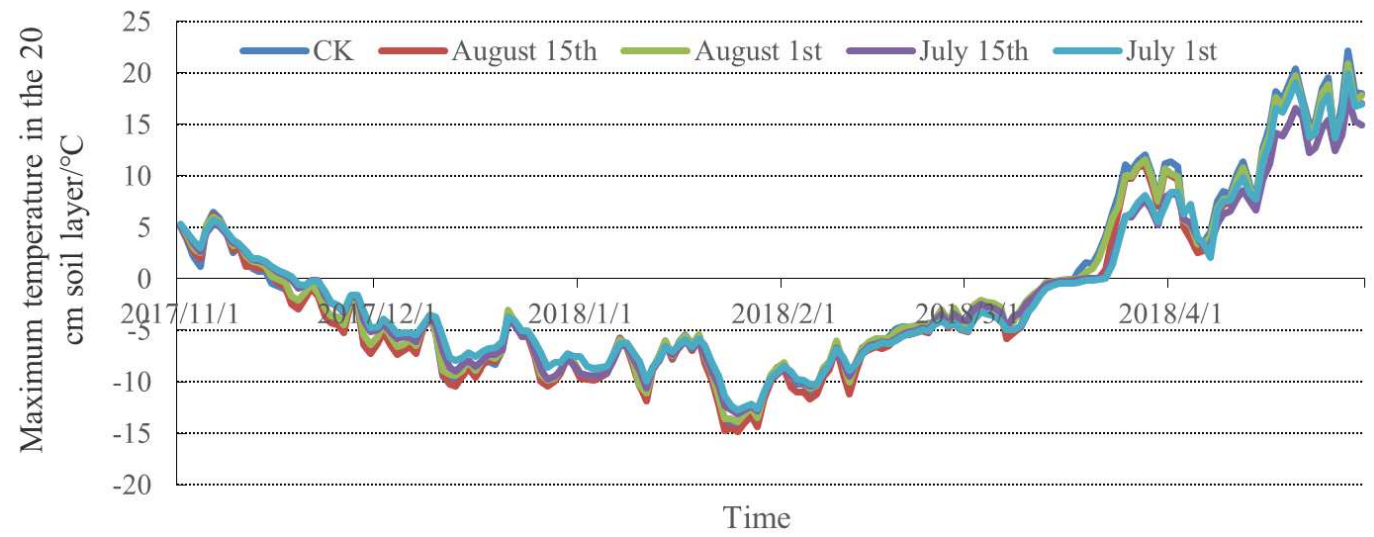

Figure 4. Change in the daily maximum temperature of the $20 \mathrm{~cm}$ soil layer from November 2017 to April 2018 under alfalfa sown on different sowing dates.

\subsubsection{Effect of Sowing Time on Diurnal Difference in Soil Temperature}

The effects of the different sowing dates on the soil temperature under alfalfa in the sandy land during winter are shown in Figures 5 and 6. After November 15, there were clear differences among the different sowing treatments in terms of the diurnal temperature difference. The average diurnal temperature differences in the $10 \mathrm{~cm}$ soil layers under bare land and alfalfa sown on 15 August, 1 August, 15 July and 1 July were $3.92^{\circ} \mathrm{C}, 4.25^{\circ} \mathrm{C}, 3.00^{\circ} \mathrm{C}, 2.11^{\circ} \mathrm{C}, 1.99^{\circ} \mathrm{C}$, respectively, and those in the $20 \mathrm{~cm}$ soil layers were $3.94^{\circ} \mathrm{C}$, $3.20^{\circ} \mathrm{C}, 2.12^{\circ} \mathrm{C}, 1.43^{\circ} \mathrm{C}$ and $1.13^{\circ} \mathrm{C}$, respectively.

In December, the diurnal temperature differences were significantly different among sowing treatments. The average diurnal temperature differences under bare land and alfalfa sown on August 15, August 1, July 15 and July 1 were $6.24^{\circ} \mathrm{C}, 5.57^{\circ} \mathrm{C}, 3.40^{\circ} \mathrm{C}, 3.06^{\circ} \mathrm{C}$ and $2.84^{\circ} \mathrm{C}$, respectively, and those in the $20 \mathrm{~cm}$ soil layers were $4.22^{\circ} \mathrm{C}, 3.73^{\circ} \mathrm{C}$, $2.93^{\circ} \mathrm{C}, 2.13^{\circ} \mathrm{C}$ and $1.55^{\circ} \mathrm{C}$, respectively.

The variation in the diurnal temperature difference in January was similar to that in December. The average diurnal temperature differences in the $10 \mathrm{~cm}$ soil layer under bare land and alfalfa sown on August 15, August 1, July 15 and July 1 were $6.58^{\circ} \mathrm{C}, 5.60^{\circ} \mathrm{C}, 4.34^{\circ} \mathrm{C}, 3.25^{\circ} \mathrm{C}$ and $3.08^{\circ} \mathrm{C}$, respectively. The average temperature differences in the 20 $\mathrm{cm}$ soil layer were $4.53^{\circ} \mathrm{C}, 3.93^{\circ} \mathrm{C}, 3.19^{\circ} \mathrm{C}, 2.37^{\circ} \mathrm{C}$ and $1.86^{\circ} \mathrm{C}$. The largest diurnal temperature difference in January occurred on January 12, and the smallest diurnal temperature difference occurred on January 8 or 9.

In February, the average diurnal temperature difference in the $10 \mathrm{~cm}$ soil layer under the alfalfa sown on July 1 was $3.87^{\circ} \mathrm{C}$ lower than that under the alfalfa sown on August 15, while the average diurnal temperature difference in the $20 \mathrm{~cm}$ soil layer was $2.37^{\circ} \mathrm{C}$ lower. The average diurnal temperature differences in February under bare land and alfalfa sown on 15 August, 1 August, 15 July and 1 July were $7.21^{\circ} \mathrm{C}$, 
$6.59^{\circ} \mathrm{C}, 5.00^{\circ} \mathrm{C}, 3.80^{\circ} \mathrm{C}$ and $3.47^{\circ} \mathrm{C}$, respectively; the average diurnal temperature differences in the $20 \mathrm{~cm}$ soil layer were $4.93^{\circ} \mathrm{C}, 4.37^{\circ} \mathrm{C}, 3.59^{\circ} \mathrm{C}, 2.72^{\circ} \mathrm{C}$ and $2.00^{\circ} \mathrm{C}$, respectively.

In March, the diurnal temperature differences fluctuated. The smallest diurnal temperature differences occurred in the $10 \mathrm{~cm}$ soil layer under the July 1 plot, the largest diurnal temperature differences occurred under the August 15 plot, and the differences fluctuated under bare land and the alfalfa sown on August 1. In the $10 \mathrm{~cm}$ soil layer, the average diurnal temperature differences under bare land and the alfalfa sown on August 15, August 1, July 15 and July 1 were $5.82^{\circ} \mathrm{C}, 6.78^{\circ} \mathrm{C}, 5.24^{\circ} \mathrm{C}, 4.06^{\circ} \mathrm{C}$ and $3.47^{\circ} \mathrm{C}$, respectively. In the $20 \mathrm{~cm}$ soil layer, the largest temperature differences occurred under bare land, those under the plot sown on July 1 were the smallest, and those in the August 15 and July 31 plots fluctuated. The change trend of the diurnal temperature difference in the $20 \mathrm{~cm}$ soil layer is similar to that in the 10 $\mathrm{cm}$ soil layer. The average diurnal temperature differences in the $20 \mathrm{~cm}$ soil layer were $4.02^{\circ} \mathrm{C}, 3.41^{\circ} \mathrm{C}, 3.38^{\circ} \mathrm{C}, 2.20^{\circ} \mathrm{C}$ and $1.90^{\circ} \mathrm{C}$ under bare land and the alfalfa sown on August 15 , August 1, July 15 and July 1, respectively.

In April, the smallest diurnal temperature difference in the $10 \mathrm{~cm}$ soil layer was observed in the July 1 plot, followed by those in the July 15, August 15, bare land and July 31 plots. The average diurnal temperature differences in April in the $10 \mathrm{~cm}$ soil layer under bare land and alfalfa sown on August 15 , August 1 , July 15 and July 1 were $8.22^{\circ} \mathrm{C}, 9.08^{\circ} \mathrm{C}$, $8.54^{\circ} \mathrm{C}, 7.19^{\circ} \mathrm{C}$ and $6.54^{\circ} \mathrm{C}$, respectively, and the average diurnal temperature differences in the $20 \mathrm{~cm}$ soil layer were $6.56^{\circ} \mathrm{C}, 5.71^{\circ} \mathrm{C}, 5.69^{\circ} \mathrm{C}, 3.75^{\circ} \mathrm{C}$ and $5.02^{\circ} \mathrm{C}$, respectively.

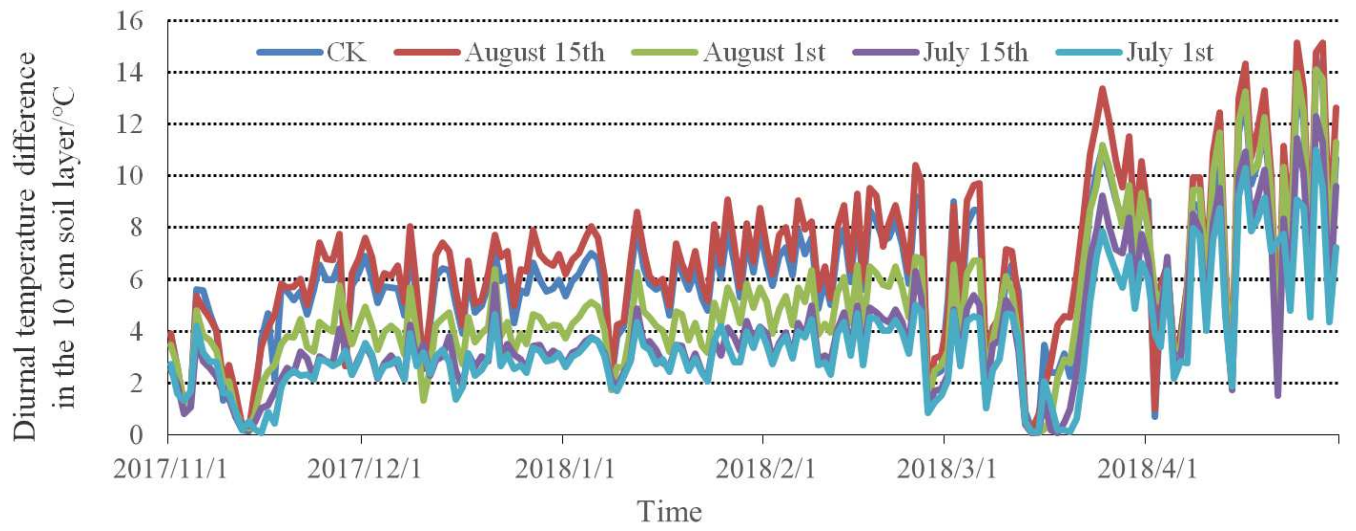

Figure 5. Diurnal temperature differences in the $10 \mathrm{~cm}$ soil layer from November 2017 to April 2018 under alfalfa sown on different sowing dates.

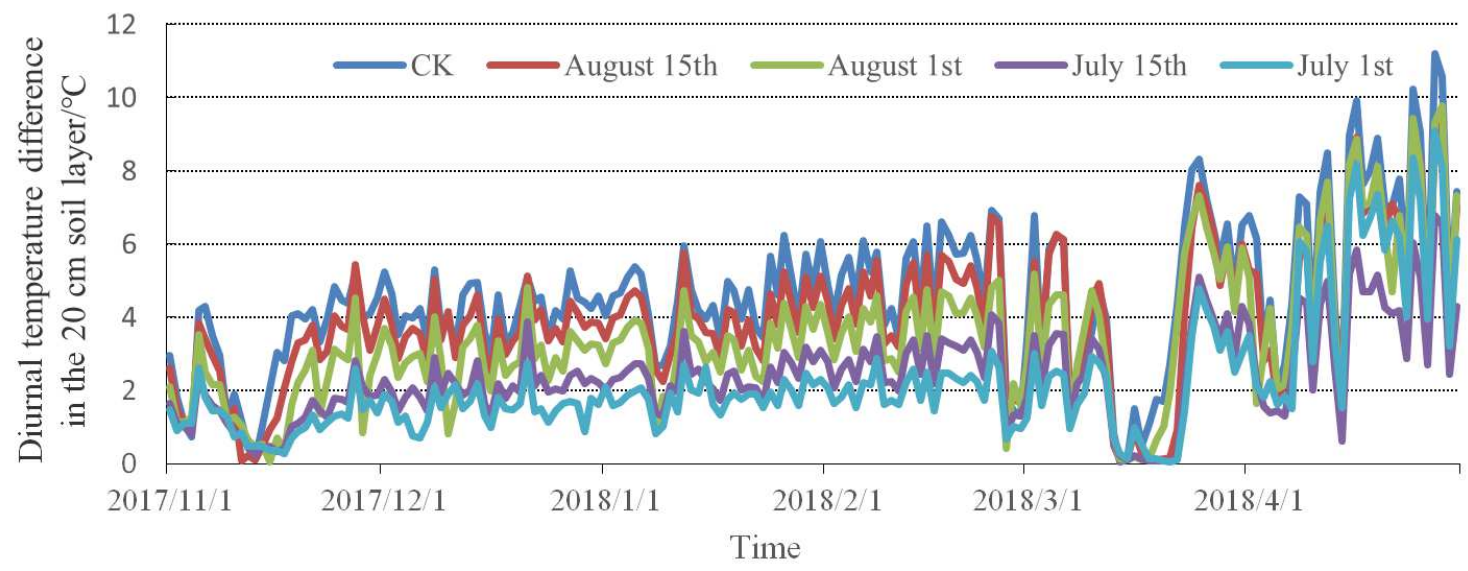

Figure 6. Diurnal temperature differences in the $20 \mathrm{~cm}$ soil layer from November 2017 to April 2018 under alfalfa sown on different sowing dates.

\section{Discussion}

\subsection{Response of Alfalfa Growth Characteristics to Sowing Date}

The selection of an appropriate sowing time is of great significance for normal alfalfa growth and development, but the appropriate sowing time for alfalfa varies greatly among different regions. Liu and Qiao [16] showed that the latest possible sowing time for alfalfa to overwinter safely was in early October and that early sowing was beneficial to alfalfa overwintering in Hebei Province. The study of Zhang et al [17] in Heilongjiang Province showed that the latest sowing time to ensure safe overwintering in alfalfa could be no later than August 20. In the Horqin area, alfalfa is sown in spring or autumn. However, due to the strong winds and sandstorms in spring, alfalfa is difficult to plant successfully in spring. Therefore, most companies and herders choose to plant alfalfa in autumn. Of course, planting alfalfa in autumn also has certain risks. Due to the large planting areas in the region, the planting period often lasts until early August or even longer, and the normal growth and development of alfalfa are 
greatly affected by the late planting date.

Plant height, root crown diameter and hay yield are the main indexes used to measure the growth characteristics of alfalfa. This study showed that early sowing was conducive to increased aboveground biomass, plant height, root crown diameter and branch number per plant in alfalfa and that the growth of alfalfa sown after August was limited. These findings are consistent with previous research results [18-19]. When the sowing time was delayed, especially when it was delayed to after August, the soil temperature during alfalfa growth dropped significantly, the temperatures at night were low, the growth and development of alfalfa plants was slow, the plants themselves were small, most of the plants had only one branch, and their growth was weak; this last factor was extremely unfavorable to alfalfa overwintering. In this study, the overwintering survival rates of alfalfa sown on July 1 and July 15 were significantly higher than those of alfalfa sown on August 1 and August 15. Therefore, sowing alfalfa from the beginning of July to July 15 in the Horqin region is likely to ensure normal alfalfa growth and development, which are conducive to successful alfalfa overwintering.

\subsection{Analysis of the Relationship Between Temperature Changes in the $10 \mathrm{~cm}$ and $20 \mathrm{~cm}$ Soil Layers and Cold Resistance in Alfalfa Sown on Different Sowing Dates}

To pursue greater economic benefits, alfalfa planting companies and herders usually harvest alfalfa at the end of autumn. The results of this study showed that the last cutting had an important effect on alfalfa overwintering that was reflected mainly in its influence on soil temperature. The branch weight per plant is an important component of the aboveground biomass of alfalfa, and the correlation analysis in this study showed that the plant height and number of aboveground branches were significantly positively correlated with the overwintering survival rate of alfalfa. The greater the plant height and number of branches per plant in early-sown alfalfa were, the thicker the aboveground coverage was, and the greater the impact on the soil temperature was. Previous studies on the influence of mulch on soil temperatures in alfalfa fields are few, and some have focused mainly on the influence of natural snow or cattle and sheep manure on the alfalfa overwintering rate. Li et al [20] and Yue et al [21] showed that a certain depth of snow cover effectively improves the overwintering survival rate of alfalfa. Li et al [22] showed that the overwintering survival rate of alfalfa covered with sheep manure was $70.5 \%$ and that the survival rate of alfalfa without sheep manure was the lowest in that study, at only $2.2 \%$. This indicated that snow cover and sheep manure can have a strong influence on the overwintering survival rate of alfalfa.

Snow cover in winter can prevent air from directly contacting the soil, buffer changes in winter soil temperatures, melt the permafrost layer, increase soil moisture levels, affect the soil temperature and physical and chemical properties, and indirectly affect the overwintering of forage [23-24]. Our study found that the aboveground biomass of early- and late-sown alfalfa had a significant effect on the soil temperature. Compared with that of alfalfa sown on August 15, the aboveground biomass of alfalfa sown on July 1 increased the average diurnal temperature difference in the $10 \mathrm{~cm}$ and $20 \mathrm{~cm}$ soil layers by $3.12^{\circ} \mathrm{C}$ and $2.99^{\circ} \mathrm{C}$, respectively, and reduce the average diurnal temperature difference by $3.33^{\circ} \mathrm{C}$ and $2.15^{\circ} \mathrm{C}$. Walker [25] showed that a change of even $1^{\circ} \mathrm{C}$ in soil temperatures can cause significant changes in plant growth. In this study, changes in the soil temperature of $2^{\circ} \mathrm{C}$ to $3{ }^{\circ} \mathrm{C}$ caused by the aboveground biomass undoubtedly had an important impact on alfalfa overwintering. The correlation analysis showed that the overwintering survival rate of alfalfa was significantly correlated with the average minimum temperature and the diurnal temperature difference in the 10 $\mathrm{cm}$ and $20 \mathrm{~cm}$ soil layers in November, December, January and February.

We also found that there was a significant positive correlation between the maximum temperature of the $10 \mathrm{~cm}$ soil layer in March and April and the overwintering survival rate of alfalfa. In March and April, the temperature fluctuates due to the occurrence of cold periods in late spring. In warmer weather, the lower the aboveground biomass of alfalfa is, the faster the temperature of the soil surface will rise, and the earlier the alfalfa will begin to regrow. When the temperature drops suddenly, the soil surface temperature under late-sown alfalfa drops quickly, and the temperature difference between day and night increases; these factors can cause serious freezing damage to the newly regrown alfalfa.

\section{Conclusion}

Delaying sowing in autumn will reduce the overwintering rate of alfalfa. Our research shows that the aboveground biomass of alfalfa without cutting in late autumn can be used as a layer of mulch, and in the overwintering period, it can effectively improve the temperature of $10 \mathrm{~cm}$ and $20 \mathrm{~cm}$ soil layers of alfalfa, and the more aboveground biomass, the greater the buffer effect of the temperature of $10 \mathrm{~cm}$ and 20 $\mathrm{cm}$ soil layers. In addition, the roots of early sown alfalfa are stronger, which is conducive to resist cold damage. Therefore, to ensure safe alfalfa overwintering in the Horqin area, alfalfa should be sown in early July and should not be mowed at the end of autumn. Our research has important guiding significance for the high-yield cultivation of alfalfa in cold areas.

\section{Authors' Contributions}

Ai-min Zhu was responsible for writing the paper; Qingxin Zhang and Xiao-yan Du were responsible for managing the experiment; Bai-ming Cong and Yong-lei Tian assisted Ai-min Zhu in the experiment; and Yu-xia Zhang and Xianguo Wang were responsible for the design and management of the experiment; Guo-dong Han provided help with the language and English grammar in the manuscript. 


\section{Conflict of Interest Statement}

All the authors do not have any possible conflicts of interest.

\section{Funding}

This work was supported by The Inner Mongolia Natural Science Fund Project (Grant No. 2020MS03081), Inner Mongolia Science and Technology Reserve Project (Grant No. 2018MDCB032), and National Public Welfare Industry (Agriculture) Public Welfare Projects (Grant No. 2014030482 ). The funding body had no role in the design of the study and collection, analysis, and interpretation of data and in writing the manuscript.

\section{Acknowledgements}

We are very grateful to Yan Zhou, the president of Huinong Prataculture company, and his staff for their help in planting alfalfa. Thanks to Xin Wang and Wen-hui Hou for their help in the experiment.

\section{References}

[1] Hanson A. A., Barnes D. K., Hill R. R., Madison. (1988): Alfalfa and alfalfa improvement. Alfalfa \& Alfalfa Improvement, 1988.

[2] Justin, \& James R. (1988): Alfalfa and alfalfa improvement. Soil Science, 146 (6), 469. https://doi.org/10.1097/00010694198812000-00012

[3] Bertrand A., Castonguay Y. (2003): Plant adaptations to overwintering stresses and implications of climate change. Revue Canadienne De Botanique, 81: 1145-1152. https://doi.org/10.1139/b03-129

[4] Volenec J. J., Ourry A., Joern B. C. (1996): A role for nitrogen reserves in forage regrowth and stress tolerance. Physiol Plant, 97: $\quad 185-193 . \quad$ https://doi.org/10.1111/j.13993054.1996.tb00496.x

[5] Schwab P. M., Barnes D. K., Sheaffer C. C. (1996): The relationship between field winter injury and fall growth score for 251 alfalfa cultivars. Crop Science, 36: 418-426. https://doi.org/10.2135/cropsci1996.0011183X003600020034x

[6] Wei Y. S., Lin Z. L., Zhou X. C., Ding S. R., Liu Y. C., Li F. (2017): Dynamic analysis on population growth and yield of mung bean affected by different sowing time in arid regions. Crops, 2: 109-113. https://doi.org/10.16035/j.issn.10017283.2017.02.019

[7] Zhang C. Z., Gao M. W. (2014): A survey on overwinter rate of alfalfa crop in Aluhorqin Banner. Grassland and Prataculture, 26: 28-29. http://dx.chinadoi.cn/10.3969/j.issn.2095-5952.2014.01.008

[8] Zhu A. M., Zhang Y. X., Wang X. G., Tian Y. L. (2018): Effects of autumn cutting on the non-structural carbon and nitrogen content in the root collar of alfalfa. Acta $\begin{array}{lll}\text { Prataculturae } & \text { Sin, } & \text { 86-96. }\end{array}$ https://doi.org/10.11686/cyxb2017116
[9] Bélanger G., Rochette P., Castonguay Y., Bootsma A., Mongrain D., Ryan D. A. J (2002): Climate change and winter survival of perennial forage crops in Eastern Canada. European Journal of Clinical Nutrition, 94: 1120-1130. https://doi.org/10.2134/agronj2002.1120

[10] Nan L. L., Shi S. L., Chen J. G., Zhu X. Q., Zhao W. H. (2011): Field evaluation of the response and resistance to low temperature of alfalfa root with different root types during over-wintering. Chinese Journal of Eco-Agriculture, 19: 619625. https://doi.org/10.3724/SP.J.1011.2011.00619

[11] Leep R., Andresen J., Jeranyama P. (2001): Fall dormancy and snow depth effects on winterkill of alfalfa. Agronomy Journal, 93: 1142-1148. https://doi.org/10.2134/agronj2001.9351142x

[12] Xie C. J., Wang P., Chen J. (2019): Effects of different mulching satterns on soil moisture, temperature, and potato yield. Chinese Journal of Soil Science, 50 (5): 1151-1158. https://doi.org/10.19336/j.cnki.trtb.2019.05.20

[13] Mashingsidze A. B., Chivinge O. A., Zishiri C. (1996): The effects of clear and blank mulch on soil temperature weed seed vailability seedling emergence, growth and yield of tomatoes. Journal of Applied Science in Southern Africa, 2 (1): 6-14. https://doi.org/10.4314/jassa.v2i1.16871

[14] Ramakrishna A., Tam H. M., Wani S. P., Long T. D. (2006): Effect of mulch on soil temperature, moisture, weed infestation and yield of groundnut in northern Vietnam. Field Crops $\quad$ Research, $95 \quad$ (2-3): 115-125. https://doi.org/10.1016/j.fcr.2005.01.030

[15] Li P. C., Guo S. J., Li M., Su X. D., Wang Q. (2014): Effects of Different Insulation Materials for Covering Soil on Gobi Ground Grape Over-Wintering. Hubei Agricultural Sciences, 53 (12): 2838-2840. https://doi.org/10.14088/j.cnki.issn04398114.2014.12.047

[16] Liu G. B., Qiao R. F. (2005): The Primary report on the introduction and selection of alfalfa varieties in Hebei low land plain. J. Hebei Agricultural Science, 82-86. https://doi.org/10.16318/j.cnki.hbnykx.2005.01.023

[17] Zhang R. H., Cai D. J., Zhu G. S., Wan J. P. (2005): Sowing time test of alfalfa varieties in Heilongjiang reclamation area. Modern Agriculture, 24-25. http://dx.chinadoi.cn/10.3969/j.issn.1001-0254.2005.03.013

[18] Hou F. Q., Li G. (2004): Study on best sowing date of alfalfa in autumn. Pratacultural Science, 21: 26-29. https://doi.org/10.1007/BF02873091

[19] Tian Y. L., Wang X. G., Zhang Y. X., Zhang S. X., Jing Z., Cong B. M., Mu Z. J., Bai C. L. (2020): Effects of different sowing dates on alfalfa production performance and overwintering rate in sandy land. Acta Agrestia Sinica, 28 (02): 538-546. https://doi.org/10.11733/j.issn.1007-0435.2020.02.030

[20] Li R. L., Shen X. H., Jiang C., Li Z. M., Zheng H. Y., Feng P. (2016): Effects of snow cover on alfalfa over-wintering and turning green. Chinese Journal of Grassland, 38: 67-73+92. https://doi.org/10.16742/j.zgcdxb.2016-01-11

[21] Yue Y. F., Wang X. Z., Miao F., Lu W. H., Ma C. H. (2016): Effects of snow cover thickness on cold resistance and winter survival rates in alfalfa cultivars with different fall dormancies. Acta Prataculturae Sin, 25: 98-106. https://doi.org/10.11686/cyxb2015474 
[22] Li W., Wang X. H., Zhao D. Z., Li G. M. (2002): Influence of different covering treatments on Medicago Sativa Capability of over wintering around Qinghai lake area. Qinghai Prataculture, 11

14-15. http://dx.chinadoi.cn/10.3969/j.issn.1008-1445.2002.04.006

[23] Wang S. Y., Wang J. Z., Song G. L. (2014): Study on the impact of artificial snow covering thickness on the growth of football turf in winter and spring. Grassland and Turf, 34: 3948. https://doi.org/10.13817/j.cnki.cyycp.2014.05.008
[24] Wang Y. T., Hu C. Y., Yang D. M., Zhang W. J., Zuo H. J. (2008) The influence of accumulated snow thickness on the turning green of the forage on Xilingol grassland. Chinese Journal of $\quad$ Grassland, 30: 15-20. https://doi.org/10.3724/SP.J.1005.2008.01083

[25] Walker J. M. (1969): One-degree increments in soil temperatures affect maize seedling behavior. Soil Sci Soc Am Proc, 33: 729736. https://doi.org/10.2136/sssaj1969.03615995003300050031x 